\title{
SOUTH AfRICAN FIRM-LEVEL EVIDENCE OF THE LINKS BETWEEN FINANCE AND EFFICIENCY
}

\author{
Waldo Krugell* \\ North West University \\ Waldo.Krugell@nwu.ac.za \\ Marianne Matthee \\ North West University \\ Marianne.Matthee@nwu.ac.za
}

December 2011

\begin{abstract}
Small and medium-sized enterprises are often seen as drivers of economic growth and development by generating employment opportunities. However, for SMEs to be successful they need finance. Access to finance has been found to be a major obstacle to SMEs' ability to do business in South Africa. This paper takes a closer look at firms, their access to finance and output per worker in South Africa, by using data from the World Bank Enterprise Survey 2007. The results show that firms that are financially constrained are more vulnerable to shocks and competition, and are weaker contributors to employment creation and growth. These firms are typically small and less established. They hold less inventory, have lower capacity utilisation and are unlikely to be exporters or to introduce new products in response to competition. The results from the regression model confirm that access to finance and different sources of finance are drivers of productivity at firm level.
\end{abstract}

Keywords

Efficiency, finance, access to finance, sources of finance, small and medium enterprises, South Africa

\footnotetext{
*Prof Waldo Krugell is professor in the School of Economics, North West University, Potchefstroom Campus, Potchefstroom, South Africa.

\#Prof Marianne Matthee is an associate professor in the School of Economics, North West University, Potchefstroom Campus, Potchefstroom, South Africa.
} 


\section{INTRODUCTION}

Employment creation is the one of the most significant challenges facing the South African economy today (Fourie, 2011). In the first quarter of 2010, the official unemployment rate was $25.2 \%$ (StatsSA, 2010). Recently, a joint declaration by manufacturers and trade unions called on government, employers and workers "to act against deindustrialisation of our economy, and create decent jobs on a large scale" (Anon., 2010:1). However, as in many developing countries, employment in large firms is low. Part of the solution to South Africa's unemployment problem can be job creation by small and medium-sized enterprises (SMEs). SMEs are often argued to be drivers of economic growth and development (see Naudé, 2008). SMEs contribute to the diversification of economic activities and thereby promote broad-based economic growth. They also generate employment opportunities and in this way contribute to reductions in poverty. Since the 1995 White Paper on Small Business, government has seen three key roles for SMEs: as agents of employment promotion, redistribution and increased competitiveness (Rogerson, 2004).

There are many factors that determine whether firms are able to grow and create employment. Magruder (2009) argues that entrepreneurial opportunities may be limited by a lack of skills, limited access to finance or a high level of crime. Rogerson (2008) states that issues of finance, training and regulation have been a continuous thread through policy discussions of the development of SMEs. This article examines access to finance and sources of finance as determinants of the role that firms can play in growth and employment creation in South Africa.

The analysis draws on data from the World Bank Enterprise Survey 2007. This survey provides firm-level information about production, sales, costs and sources of financing, which allows one to model firm performance as a function of access to finance and its sources of finance. The article is structured as follows: Section 2 provides a brief overview of the literature, explaining some of the theory and evidence of how finance links with firm growth and employment creation. Section 3 describes the data from the World Bank Enterprise Survey 2007 and what it says about firms and the patterns of finance in South Africa. In Section 4, the results of a regression analysis of firm performance, modelled as a function of access to finance and sources of finance, are presented. Section 5 concludes and makes a number of recommendations for further research.

\section{LITERATURE REVIEW}

The majority of firms are, in most economies, small and medium-sized. According to the 0ECD (2006), between $95 \%$ and $99 \%$ of all firms are SMEs, depending on the country. They also make a significant contribution to job creation: SMEs account for around $60 \%$ to $70 \%$ of job creation in the $0 \varepsilon C D$ countries (OECD, 2006). Newberry (2006) summarises other benefits of SMEs to an economy. He states that they are, for example, more diverse and flexible than larger firms and are therefore able to cope better with fluctuating conditions in the economy. SMEs also assist in the transition process from a resource-oriented economy to an industrial-and service-oriented one. Newberry (2006) finds that SMEs donate to charities in their communities, thereby contributing to reduced inequality and development of their communities. Many SMEs are often labour intensive and employ low-skilled workers who may otherwise have been unemployed. 
For SMEs to be able to create jobs and benefit an economy, they need to grow. Numerous studies have examined the determinants of firm growth. Dobbs and Hamilton (2007) provide a review of the literature on the determinants of the growth of small firms, while Nichter and Goldmark (2009) report on small firm growth in developing countries. The factors that influence small firm growth are grouped into the characteristics of the entrepreneur (e.g. education and experience), the characteristics of the firm (e.g. size, age and access to finance) and other external or environmental factors (e.g. demand and regulation).

Of these determinants of the growth of firms, a significant amount of literature exists on the importance of access to finance (see Newberry, 2006; 0ECD, 2006). Claessens and Tzioumis (2006:8) define access to finance as "the availability of supply of quality financial services at reasonable costs". Access to finance is a driver of growth in that finance is required for the start-up of an $S M E$, the development of new products and the expansion of the firm. In all of these stages, finance is required for investment in equipment and employees (OECD, 2006). The need for finance depends on the size of the firm, the age of the firm and the type of firm. For example, compared to the average firm, older, slower-growing firms do not have the same need for working capital as young, faster-growing firms. Similarly, manufacturing firms may require more long-term capital than retail firms, which may need finance for a shorter period (Berry et al., 2002).

Firms can use internal and external sources of finance. Internal sources include private savings of the entrepreneur and retained earnings of the firm. External sources include funds from family and friends, banks, the state and other entities (Malhotra et al., 2006). The source of finance can drive or dampen firm growth. Becchetti and Trovato (2002) found that firms with greater access to external finance (i.e. firms that have adequate leverage) are able to grow faster than firms with low leverage. The significance of the source of finance also depends on the size of the firm. Malhotra et al. (2006) state that small firms typically obtain only $30 \%$ of their financing from external sources, whereas large firms are able to source $48 \%$ of their financing externally. The positive impact of external finance is twice as large on firms that have fewer than 50 employees. In contrast, Du and Girma (2009) tested the relationship between firm size, sources of finance and growth in a study of Chinese firms over the period 1998 to 2005. Their results suggest that different sizes of firms have different sources of finance and the source of finance matters for a firm's growth. For a small firm, internal sources are vital for their growth, while external finance is important for larger firms' growth.

Since sources of finance matter for firm growth, there is a separate literature on the factors that influence firms' access to finance. Claessens and Tzioumis (2006) summarise empirical evidence on these factors. The main factors found to influence firms' access to finance include the age and size of a firm, the development of the financial system and capital markets and the presence of private credit registries, among other factors. Size and age account for most of the differences in access to finance between firms. The general conclusion is that smaller firms experience greater financial obstacles in that they have more limited access to formal sources of external finance (Berry et al., 2002; Beck \& Demirgüç-Kunt, 2006). When a small firm is able to survive, its production and growth potential are limited by the availability of external finance (Becchetti \& Trovato, 2002). Limited financial sources constrain small firms' annual growth twice as much as they do that of larger firms (Beck \& Demirgüç-Kunt, 2006). Beck et al. (2006) used survey data of 10000 firms from 80 countries to study the determinants of financing obstacles. They also found differences pertaining to firm size and age. Firms that are larger and older than average report fewer financing obstacles, while the smaller and younger firms are more constrained. The effect is even more pronounced in developing countries. 
There are numerous SME studies in South Africa, and Rogerson (2008) provides an overview of the literature on SME development, focusing on the issues of finance, training and the regulatory environment. In an earlier review of the impact of the South African government's SME programmes, Rogerson (2004) stated that the statistics on the SME economy in South Africa are dismal. He notes remarkable differences in the estimates of the numbers of SMEs: figures by the Ntsika Enterprise Promotion Agency show a national total of approximately 1.1 to 1.2 million SMEs, whereas StatsSA estimated that in March 2001 there were approximately 2.3 million people who were owners of at least one non-VAT-registered business (Rogerson, 2004). Falkena et al. (2001) estimated that, at the end of the 1990s, South Africa had approximately 906700 firms, of which only 6000 were large firms. The importance of South Africa's SMEs for growth and employment creation is even more difficult to determine. Earlier studies have shown that net employment growth generated by SMEs takes the form of new micro-enterprise formation, but the growth of micro- and small firms is limited. Medium-sized firms tend to be more dynamic and responsible for new employment (Rogerson, 2004).

Analyses of the development of SMEs have examined the significance of finance, human capital and institutions or regulation. Rogerson's (2008) review refers to demand-side research that examines the importance of access to finance and the financing requirements of SMEs. The early work is based on surveys conducted by the World Bank and reported by Chandra et al. (2001) and Skinner (2005).

Chandra et al. (2001) studied 792 manufacturing firms in the greater Johannesburg area to determine the constraints to growth and employment in South Africa from a firm-level perspective. They found that most of the small firms in their survey made use of internal sources (private savings and retained earnings) to finance their capital requirements. Only a small number of firms obtained finance from external sources such as banks. Approximately $29 \%$ of firms used private savings (family savings), $49 \%$ used individual savings and $10 \%$ used retained earnings as sources of investment capital. Around $24 \%$ used banks and the rest used other sources of start-up capital, such as retrenchment packages and government agencies. Working capital, on the other hand, is often financed through private savings. Lack of collateral is cited as a reason why firms in the survey experience difficulty in accessing financial markets.

Skinner (2005) examined the informal economy through a survey of 507 informal enterprise owners operating in the Durban municipal area. It was found that a lack of funds or access to credit was the most frequently cited problem for the respondents. Over $50 \%$ of these informal enterprises started with R1000 or less, in most cases from the personal savings of the owner or supplied by relatives or friends. Only $3.9 \%$ of the respondents had ever accessed a bank loan for business purposes. Most of the owners cited high costs, a lack of collateral and complicated procedures as reasons for not trying to obtain a loan, or why their loan application was unsuccessful.

Rogerson's (2008) review also covers a range of other contributions to the literature. A FinMark Trust Survey found that access to finance is a significant issue in SMME development and constrains the development of the informal sector. A number of studies examined the issues of gendered access to finance. A 2006 survey by the World Bank found that micro-enterprises differ significantly from formal SMEs and large enterprises in terms of access to finance.

In summary, the literature indicates that small firms can play a significant role in employment creation and economic growth. There are many drivers of firm growth, but a key determinant is access to finance. The following section takes a closer look at the issue of firms and access to finance in South Africa by using data from the World Bank Enterprise Survey 2007. 


\section{FIRMS AND FINANCE IN THE WORLD BANK SURVEY DATA}

In South Africa, firm-level data presents particular challenges to researchers. Rankin (2006) explains that a number of firm-level surveys have been carried out in South Africa, but they have been $a d$ hoc and the surveys have not always been designed for quantitative analysis. Given these constraints, this paper employs data from the 2007 World Bank Enterprise Survey. The survey was national in scope and covered different sectors. TABLE 1 shows the city and industry coverage of the survey.

TABLE 1: Enterprise survey description, numbers of firms by location, sector and size

\begin{tabular}{|c|c|c|c|c|c|}
\hline Industry & $\begin{array}{c}\text { Johannes- } \\
\text { burg }\end{array}$ & Cape Town & $\begin{array}{c}\text { Port } \\
\text { Elizabeth }\end{array}$ & Durban & Total \\
\hline Other manufacturing & 112 & 34 & 13 & 21 & 180 \\
\hline Food & 86 & 16 & 11 & 9 & 122 \\
\hline Textiles & 4 & 3 & 0 & 4 & 11 \\
\hline Garments & 68 & 18 & 10 & 12 & 108 \\
\hline Chemicals & 51 & 16 & 9 & 7 & 83 \\
\hline Plastics and rubber & 14 & 3 & 2 & 3 & 22 \\
\hline Non-metallic mineral products & 2 & 5 & 0 & 1 & 8 \\
\hline Basic metals & 2 & 0 & 0 & 0 & 2 \\
\hline Fabricated metal products & 71 & 13 & 5 & 21 & 110 \\
\hline Machinery and equipment & 25 & 6 & 0 & 3 & 34 \\
\hline Electronics & 15 & 1 & 3 & 3 & 22 \\
\hline Construction & 10 & 3 & 0 & 3 & 16 \\
\hline Other services & 15 & 1 & 0 & 9 & 25 \\
\hline Wholesale & 7 & 0 & 0 & 7 & 14 \\
\hline Retail & 181 & 22 & 8 & 18 & 229 \\
\hline Hotels and restaurants & 53 & 2 & 5 & 5 & 65 \\
\hline Transport & 0 & 1 & 0 & 1 & 2 \\
\hline Information technology & 3 & 1 & 0 & 0 & 4 \\
\hline \multicolumn{6}{|l|}{ Firm size } \\
\hline Small (5-19 employees) & 243 & 60 & 30 & 42 & 375 \\
\hline Medium (20-99 employees) & 231 & 53 & 19 & 63 & 366 \\
\hline Large (100 employees and more) & 125 & 32 & 17 & 22 & 196 \\
\hline
\end{tabular}

Source: Authors'calculations from the World Bank Enterprise Survey, 2007

TABLE 1 shows that the greatest number of firms surveyed were located in Johannesburg, followed by Cape Town and Durban. The sectors from which the majority of the firms were drawn were retail $(21.7 \%)$, other manufacturing $(17 \%)$, food (11.5\%), fabricated metals $(10.4 \%)$ and garments $(10.2 \%)$. In total, the survey reached 375 small firms, 366 medium-sized firms and 196 large firms. A cross-tabulation of industries and firm size shows that the small firms were to be found in the retail and wholesale sectors, garments and other manufacturing. Medium-sized firms were prevalent in textiles, chemicals, plastics and rubber, as well as other services and the 
wholesale trade. The large firms were concentrated in base metals, non-metallic mineral products and electronics.

Further description of the data reveals that the majority of the firms had private domestic owners. There was very limited foreign ownership of the small and medium-sized firms (on average $7 \%$ and $5 \%$ respectively), but on average $24 \%$ of ownership was in foreign hands in the case of the large firms. The Enterprise Survey questionnaire also asked whether any of the owners were non-whites. Approximately $45 \%$ of small firms, $28 \%$ of medium-sized firms and $16 \%$ of large firms indicated that some of their owners were non-whites. The firms reached by the survey were well established, with a mean age of 21 years. The small firms were on average nine years old, the medium-sized firms 18 years old and the large firms on average 31 years. Many of the firms were exporters and $5 \%$ of small firms, $18 \%$ of medium-sized firms and $45 \%$ of large firms had exported in 2006.

The survey was an investment climate assessment, and in addition to questions about sales and exports, the questionnaire also asked firms about supplies and imports, capacity and innovation, investment climate constraints, infrastructure and services, relations between business and government, labour relations and finance. With specific reference to finance, the survey provides information about sources of financing, current lines of credit or loans, collateral and the reasons why firms' loan applications were rejected. FIGURE 1 shows firms' view on obstacles to their operations. Specifically, it shows their first choice of 'the most severe obstacle to operations'. Crime, theft and disorder were viewed as the most severe obstacles to operations, followed by electricity, access to finance, an inadequately educated workforce and corruption. Another $9 \%$ of firms saw access to finance as the second most serious obstacle that they faced and an additional $6 \%$ saw it as the third most serious obstacle.

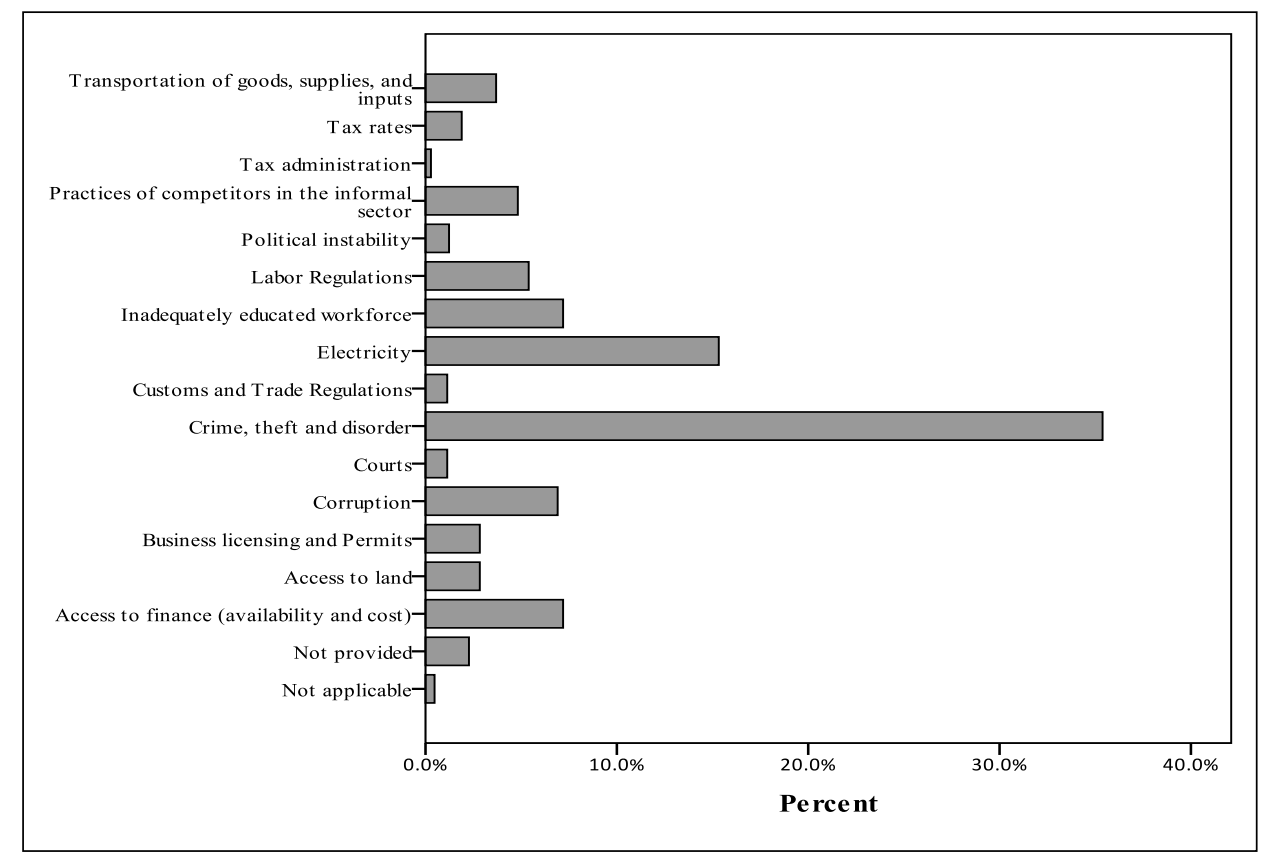

\section{FIGURE 1: Obstacles to operations}

Source: Authors'calculations from the World Bank Enterprise Survey, 2007 
A cross-tabulation of the perceived obstacle with firm size in TABLE 2 shows that a larger percentage of small firms viewed access to finance as a serious obstacle to operations as compared to medium-sized and large firms.

TABLE 2: Access to finance as an obstacle to operations and firm size

\begin{tabular}{|c|c|c|c|c|}
\hline & & $\begin{array}{l}\text { Small (5-19 } \\
\text { employees) }\end{array}$ & $\begin{array}{c}\text { Medium (20-99 } \\
\text { employees) }\end{array}$ & $\begin{array}{l}\text { Large (>100 } \\
\text { employees) }\end{array}$ \\
\hline \multirow{3}{*}{ No Obstacle } & Count & 224 & 235 & 155 \\
\hline & $\begin{array}{l}\% \text { within access } \\
\text { to finance }\end{array}$ & $36.5 \%$ & $38.3 \%$ & $25.2 \%$ \\
\hline & $\%$ within size & $59.7 \%$ & $64.2 \%$ & $79.1 \%$ \\
\hline \multirow{3}{*}{ Minor Obstacle } & Count & 34 & 53 & 24 \\
\hline & $\begin{array}{l}\% \text { within access } \\
\text { to finance }\end{array}$ & $30.6 \%$ & $47.7 \%$ & $21.6 \%$ \\
\hline & $\%$ within size & $9.1 \%$ & $14.5 \%$ & $12.2 \%$ \\
\hline \multirow{3}{*}{$\begin{array}{l}\text { Moderate } \\
\text { Obstacle }\end{array}$} & Count & 45 & 40 & 6 \\
\hline & $\begin{array}{l}\% \text { within access } \\
\text { to finance }\end{array}$ & $49.5 \%$ & $44.0 \%$ & $6.6 \%$ \\
\hline & $\%$ within size & $12.0 \%$ & $10.9 \%$ & $3.1 \%$ \\
\hline \multirow{3}{*}{ Major Obstacle } & Count & 54 & 29 & 7 \\
\hline & $\begin{array}{l}\% \text { within access } \\
\text { to finance }\end{array}$ & $60.0 \%$ & $32.2 \%$ & $7.8 \%$ \\
\hline & $\%$ within size & $14.4 \%$ & $7.9 \%$ & $3.6 \%$ \\
\hline \multirow{3}{*}{$\begin{array}{l}\text { Very Severe } \\
\text { Obstacle }\end{array}$} & Count & 18 & 9 & 4 \\
\hline & $\begin{array}{l}\% \text { within access } \\
\text { to finance }\end{array}$ & $58.1 \%$ & $29.0 \%$ & $12.9 \%$ \\
\hline & $\%$ within size & $4.8 \%$ & $2.5 \%$ & $2.0 \%$ \\
\hline
\end{tabular}

Source: Authors' calculations from the World Bank Enterprise Survey, 2007

Thus, it is possible to distinguish between those firms that viewed access to finance as a major or very severe obstacle $(n=155)$, and the others for whom access to finance was no obstacle, a minor or moderate obstacle $(n=902)$. A further examination of the characteristics of the firms for which access to finance was an obstacle presents an interesting profile. These firms are found in the retail, other manufacturing and garments sectors. The mix of private and foreign ownership does not differ between the two types of firms. However, the firms that viewed access to finance as an obstacle were markedly younger (average nine years) than the firms that did not (average 19 years). Only $3.9 \%$ of exporters indicated that access to finance was an obstacle to their operations.

TABLE 3 presents information about sales and supplies. Firms that indicated that access to finance was an obstacle to their operations were not able to allow their clients to pay after delivery and more of their sales were paid for before or on delivery. These firms also had to pay for their purchases before or on delivery. Their financial constraint is also clear in the fact that they held half the days of inventory held by the firms that did not see access to finance as an obstacle to operations. 
TABLE 3: Sales and supplies comparison of firms

\begin{tabular}{|c|c|c|}
\hline Means & No obstacle & $\begin{array}{c}\text { Access to finance is an } \\
\text { obstacle }\end{array}$ \\
\hline$\%$ sales paid before delivery & 10.42 & 24.28 \\
\hline$\%$ sales paid on delivery & 38.11 & 45.02 \\
\hline$\%$ sales paid after delivery & 51.48 & 30.70 \\
\hline$\%$ purchases paid before delivery & 12.93 & 23.62 \\
\hline$\%$ purchases paid on delivery & 27.95 & 45.77 \\
\hline$\%$ purchases paid after delivery & 59.16 & 30.61 \\
\hline days of inventory & 22.58 & 11.10 \\
\hline years known supplier & 11.59 & 7.55 \\
\hline
\end{tabular}

Source: $\quad$ Authors' calculations from the World Bank Enterprise Survey, 2007

Capacity utilisation by the two types of firms was similar. The firms that did not view access to finance as a constraint used on average $79 \%$ of capacity and those that did had slightly lower capacity utilisation at $77 \%$. As regards innovation, the survey also asked the firms whether they introduced new products in response to domestic competition. A cross-tabulation with the access to finance measure shows that for $94 \%$ of the firms that introduced new products, access to finance was not a constraint. In terms of operations, the firms that are constrained by access to finance were also more vulnerable to the effects of the other major obstacles to doing business such as the electricity supply and crime. They were less likely to own a generator or use own transport to make shipments, and their firms were also less likely to pay for security or to provide formal training.

The differences between firms that viewed access to finance as a constraint and those that did not are also apparent from the finance items in the questionnaire. TABLE 4 shows a crosstabulation of the two types of firms and their access to banking services. Most of the firms surveyed had access to a cheque or savings account. A greater proportion of firms that regard access to finance as an obstacle to operations did not have a cheque or savings account. The scope of the problem is extended when one considers whether the firms had access to an overdraft facility. The firms that did not have access to an overdraft facility were typically also the ones that regarded access to finance as a constraint. To access loans, firms also need to have audited financial statements. TABLE 4 shows that few of the firms that regarded access to finance as an obstacle to operations had an external auditor.

In addition to access to banking services, the survey also asked firms whether they purchased fixed assets in the preceding year and how those purchases were financed. In total, 445 of the 1057 firms indicated that they purchased fixed assets in 2006. Of these, approximately $14 \%$ also viewed access to finance as a constraint to operations. Or, within the group of constrained firms, $41 \%$ invested in fixed assets and $59 \%$ did not. TABLE $\mathbf{5}$ shows how the fixed assets were financed. The numbers are means of the percentage of finance from the particular source. 
TABLE 4: Access to banking services

\begin{tabular}{|c|c|c|c|}
\hline & & No obstacle & $\begin{array}{c}\text { Access to } \\
\text { finance is } \\
\text { an } \\
\text { obstacle }\end{array}$ \\
\hline \multirow{3}{*}{ External auditor: Yes } & Count & 690 & 59 \\
\hline & $\%$ within external auditor & $92.1 \%$ & $7.9 \%$ \\
\hline & $\%$ within access to finance dummy & $76.5 \%$ & $38.1 \%$ \\
\hline \multirow{3}{*}{ External auditor: No } & Count & 212 & 96 \\
\hline & $\%$ within external auditor & $68.8 \%$ & $31.2 \%$ \\
\hline & $\%$ within access to finance dummy & $23.5 \%$ & $61.9 \%$ \\
\hline \multirow{3}{*}{ Cheque or savings account: Yes } & Count & 867 & 143 \\
\hline & $\%$ within checking/saving account & $85.8 \%$ & $14.2 \%$ \\
\hline & $\%$ within access to finance dummy & $96.1 \%$ & $92.3 \%$ \\
\hline \multirow{3}{*}{ Cheque or savings account: No } & Count & 35 & 12 \\
\hline & $\%$ within checking/saving account & $74.5 \%$ & $25.5 \%$ \\
\hline & $\%$ within access to finance dummy & $3.9 \%$ & $7.7 \%$ \\
\hline \multirow{3}{*}{ Overdraft: Yes } & Count & 503 & 53 \\
\hline & $\%$ within overdraft & $90.5 \%$ & $9.5 \%$ \\
\hline & $\%$ within access to finance dummy & $55.8 \%$ & $34.2 \%$ \\
\hline \multirow{3}{*}{ Overdraft: No } & Count & 399 & 102 \\
\hline & $\%$ within overdraft & $79.6 \%$ & $20.4 \%$ \\
\hline & $\%$ within access to finance dummy & $44.2 \%$ & $65.8 \%$ \\
\hline
\end{tabular}

Source: Authors' calculations from the World Bank Enterprise Survey, 2007

TABLE 5 shows that there are a few differences between the sources of finance for fixed assets between the firms that indicated that they view access to finance as a constraint and those that do not. The constrained firms tend to have used slightly more internal finance, supplier credit, new shares and other sources of finance, such as friends or relatives. A similar pattern holds for the sources of working capital. In that case, the finance constrained firms' use of the other sources, including moneylenders, is notable. 
TABLE 5: Finance of fixed assets purchases

\begin{tabular}{lcc}
\hline & $\begin{array}{c}\text { No obstacle } \\
(n=384)\end{array}$ & $\begin{array}{c}\text { Access to finance is an } \\
\text { obstacle }(n=64)\end{array}$ \\
\hline \% Internal finance & 68.7943 & 69.1406 \\
\% Non-bank financial institutions & 0.4167 & 1.5625 \\
\% Supplier credit & 3.8672 & 5.9375 \\
\% New shares & 0.0000 & 1.4844 \\
\% New debt & 0.0000 & 0.0000 \\
\% Other finance & 2.0052 & 5.1563 \\
\hline
\end{tabular}

Source: Authors' own calculations from the World Bank Enterprise Survey, 2007

When considering the sources of finance, taking account of firm size also provides interesting information. TABLE 6 shows the sources of finance of fixed assets and working capital per small, medium-sized and large firm. The table clearly shows that in the case of small firms a greater proportion of finance for fixed assets and working capital has to come from internal sources, compared to the medium-sized and large firms.

\section{TABLE 6: Sources of finance and firm size}

\begin{tabular}{lccc}
\hline Finance of fixed assets & Small & Medium & Large \\
\cline { 2 - 4 } & $(n=108)$ & $(n=176)$ & $(n=123)$ \\
\hline \% Internal finance & 77.5926 & 61.4773 & 69.2846 \\
\% Non-bank financial institutions & 1.0185 & 0.8523 & 0.0000 \\
\% Supplier credit & 5.0000 & 3.8068 & 4.5935 \\
\% New shares & 0.0000 & 0.0000 & 0.0000 \\
\% New debt & 0.0000 & 0.0000 & 0.0000 \\
\% Other finance & 0.2778 & 0.9943 & 2.4390 \\
Finance of working capital & Small & Medium & Large \\
\% Internal finance & $(n=375)$ & $(n=366)$ & $(n=196)$ \\
\% Non-bank financial institutions & 72.6800 & 65.0068 & 66.2092 \\
\% Supplier credit & 1.1360 & 1.1066 & 0.5357 \\
\% Other finance & 21.7707 & 23.8593 & 23.8622 \\
\hline
\end{tabular}

Source: Authors' own calculations from the World Bank Enterprise Survey, 2007

The survey also provides information about loan applications, recent loans and the collateral required. In total, $28 \%$ of the respondents had a loan with a financial institution and $20 \%$ indicated that collateral was required. The firms that did not view access to finance as a constraint to their operations were more likely to use land and buildings, machinery and equipment and accounts receivable as collateral. A greater share of the firms that viewed access to finance as a constraint used the owner's personal assets as collateral.

New applications for loans during 2006 were more prevalent among the firms that viewed access to finance as a constraint. Unfortunately, only 47 firms in total provided reasons for the rejections of their applications. Among the firms that did not see access to finance as a 
constraint, the most common reason was poor profitability. Unacceptable collateral, incomplete loan applications and poor profitability were cited as reasons for the rejection of the loan applications of firms that view access to finance as a constraint.

From the information gathered by the survey, it is clear that many firms did not even apply for loans or lines of credit. Approximately $56 \%$ of the firms that did not view access to finance as a constraint also indicated that they did not apply because they did not need a loan and had sufficient capital. Another $9 \%$ said that the interest rates were not favourable and almost $6 \%$ indicated that the application procedures were complex. Among the firms that viewed access to finance as a constraint, there are different reasons for not applying for a loan. Only $20 \%$ said that they did not need a loan. Approximately $19 \%$ were prohibited by complex application procedures, and $10 \%$ said that they did not apply because they did not think that the loan would be approved. Unfavourable interest rates and unattainable collateral requirements were also mentioned as reasons for not applying.

In summary, this brief description of the data presents a clear profile of firms and their access to finance. Firms that indicate that access to finance is a constraint to their operations are typically small and less well established. They are not able to allow their clients to pay after delivery and they have to pay for their purchases before or on delivery. These firms also hold a smaller stock of inventory. The firms that are constrained by access to finance are less likely to own a generator or use their own transport to make shipments. These firms are also less likely to pay for security or to provide formal training. They have lower capacity utilisation and are unlikely to be exporters or to introduce new products in response to competition. All of this indicates that they may be more vulnerable to shocks and competition as well as being weaker contributors to employment creation and growth.

The extent to which access to finance and different sources of finance are drivers of productivity or growth at firm level is something that requires further examination. The average value of output per worker for firms that view access to finance as a constraint is approximately R247 000. For the firms that are not financially constrained, it is R464 000. The following section presents the results of econometric analysis of the drivers of output per worker, including finance.

\section{EMPIRICAL ANALYSIS AND RESULTS}

To examine whether access to finance and sources of finance is a predictor of firm-level efficiency, the data is analysed for estimation of a production function. Following Rankin (2001), a Cobb-Douglas production function (1) is fitted to the data. The production function is estimated by taking natural logarithms of both sides. An OLS estimator is used with the correction for heteroskedasticity robust standard errors. The estimating equation takes the form:

$$
\begin{gathered}
\text { Output }_{t}= \\
f\left(a_{i}, \text { capital }_{i}, \text { labour }_{i}, \text { materials }_{i}, \text { indrect cost }_{i}, \text { sector }_{i}, \text { size }_{i}, \text { age }_{i}, \text { finance }_{i}, \text { source }_{i}\right)
\end{gathered}
$$

where:

$a_{i}$ is a firm-specific intercept,

capital $_{i}$ materials $_{i}$ and indirectcost ${ }_{i}$ represent these inputs in per worker terms, 


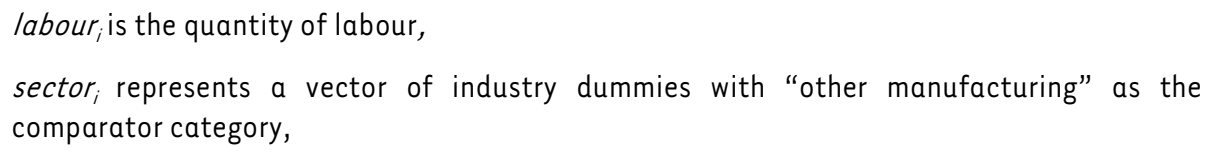
size $_{i}$ is a dummy that distinguishes between small, medium and large firms, with small firms being the comparator category,

$a g e_{\mathrm{i}}$ is the age of the firm measured in years

finance $_{i}$ is a dummy variable that indicates whether the firm views finance as a constraint

source $_{i}$ measures the firms' different sources of finance of fixed asset purchases as a percentage of the total purchases of fixed assets.

TABLE 7 presents the results of different specifications using the 2007 survey data. The table shows estimated coefficients with $t$-statistics in brackets. Model 1 presents the basic production function without additional controls. All the coefficients are positive and show significant returns. In Model 2, the access to finance dummy is added. A value of one indicates that the firms viewed access to finance as a constraint to their operations and a zero indicates that they did not see finance as a constraint. The sign of the coefficient indicates the expected inverse negative relationship between finance constrained firms and output per worker. However, in this specification, the relationship is not significant.

In Model 3, two firm size dummies are added. Medium-sized and large firms are identified and compared to small firms. The positive coefficient indicates that, compared to small firms, the medium-sized and large firms tend to produce more output per worker, but this size effect is not significant.

Model 4 adds the firm age as an explanatory variable. Being operational for longer is positively associated with output per worker and even though the coefficient is small, it is significant. In both models 3 and 4 , the additional variables do not materially affect the other results.

In the fifth and full specification of the model, the source-of-finance variables are added. These are the sources of finance used to finance fixed assets. The coefficients are rather small and insignificant, but it is clear that there is a positive association between using internal finance and supplier credit and output per worker. There is a negative relationship between output per worker and the use of non-bank financial institutions and other sources of credit, such as friends, family and moneylenders. The measures of new shares and new debt as sources of finance were dropped from the model due to an insufficient number of observations. The important impact of adding the sources of finance to the model is that the access-to-finance dummy, size dummy and firm age become significant determinants of output per worker.

Throughout, the models have a reasonably good fit for cross-sectional data, explaining between $61 \%$ and $65 \%$ of the variation in output per worker. It is not shown in TABLE 7, but models 3 through 5 were also estimated with industry dummies contrasting the manufacturing firms with the others in the sample. This did not influence the results significantly and those tables are available on request. In summary, the results show that there are not only interesting differences between firms and their access to finance, but access to finance and different sources of finance are drivers of productivity at firm level. 
TABLE 7: Regression results

\begin{tabular}{|c|c|c|c|c|c|}
\hline & Model 1 & Model 2 & Model 3 & Model 4 & Model 5 \\
\hline \multirow{2}{*}{ Constant } & 4.049 & 4.121 & 4.186 & 4.229 & 4.594 \\
\hline & $(14.71)$ & $(14.57)$ & $(14.03)$ & $(14.20)$ & $(10.79)$ \\
\hline \multirow{2}{*}{ Capital } & $0.093 *$ & $0.092 *$ & $0.093 *$ & $0.090 *$ & $0.052 \star$ \\
\hline & $(5.13)$ & $(5.09)$ & $(5.09)$ & $(4.94)$ & $(1.97)$ \\
\hline \multirow{2}{*}{ Labour } & $0.213 *$ & $0.208 *$ & $0.166 *$ & $0.139 *$ & $0.109 *$ \\
\hline & $(10.64)$ & $(10.12)$ & $(3.58)$ & $(2.94)$ & $(1.74)$ \\
\hline \multirow{2}{*}{ Materials } & $0.407 \star$ & $0.405^{\star}$ & $0.405^{\star}$ & $0.411 *$ & $0.338 *$ \\
\hline & $(13.18)$ & $(13.12)$ & $(13.08)$ & $(13.27)$ & $(8.14)$ \\
\hline \multirow{2}{*}{ Indirect cost } & $0.284 *$ & $0.282^{\star}$ & $0.281 *$ & $0.276 *$ & $0.350 *$ \\
\hline & $(10.61)$ & $(10.51)$ & $(10.42)$ & $(10.24)$ & $(9.26)$ \\
\hline \multicolumn{2}{|l|}{ Access to finance dummy } & -0.088 & -0.084 & -0.081 & $-0.246 *$ \\
\hline \multicolumn{2}{|l|}{ ( $l=$ access is a constraint $)$} & $(-1.10)$ & $(-1.05)$ & $(-1.01)$ & $(-1.92)$ \\
\hline \multirow{2}{*}{ Firm size dummy: medium } & & & 0.148 & 0.153 & $0.419 \star$ \\
\hline & & & $(1.65)$ & $(1.72)$ & $(3.23)$ \\
\hline \multirow{2}{*}{ Firm size dummy: large } & & & 0.161 & 0.162 & $0.392 \star$ \\
\hline & & & $(1.00)$ & $(1.01)$ & $(1.82)$ \\
\hline \multirow{2}{*}{ Firm age } & & & & 0.004 & $0.004 \star$ \\
\hline & & & & $(2.33)$ & $(2.03)$ \\
\hline \multirow{2}{*}{ Source of finance: Internal } & & & & & 0.001 \\
\hline & & & & & $(0.06)$ \\
\hline \multirow{2}{*}{$\begin{array}{l}\text { Source of finance: Non-bank financial } \\
\text { institution }\end{array}$} & & & & & -0.003 \\
\hline & & & & & $(-0.51)$ \\
\hline \multirow{2}{*}{ Source of finance: Supplier credit } & & & & & 0.001 \\
\hline & & & & & $(0.44)$ \\
\hline \multirow{2}{*}{ Source of finance: 0 ther } & & & & & -0.003 \\
\hline & & & & & $(-1.00)$ \\
\hline Adjusted $\mathrm{R}$ & 0.61 & 0.61 & 0.61 & 0.62 & 0.65 \\
\hline
\end{tabular}

Source: Authors'own calculations

* indicates significance at the $5 \%$ level

A caveat to keep in mind is that these models do not account for unobserved heterogeneity. It may well be that, for example, entrepreneurial ability that is not measured or modelled is related to firms' productivity and ability to access finance and failing to account for this leads to bias of the results. An option would be to use panel data techniques to control for unobserved heterogeneity. There is a 2003-06 World Bank Enterprise Survey panel for South Africa that would allow for the estimation of a fixed-effects model, but in practice there are a number of limitations. The panel is small, with only 191 firms for the two time periods. It is also unbalanced with many missing observations. Specifically, the 2003 survey did not record the value of capital in terms of replacement cost, so it would have to be measured at market value. There are no matched 2003 observations for depreciation and the costs of water, transport and communication, so there is no measure of indirect costs and a limited measure of materials 
costs.

The key point, however, is that the panel is not suitable for investigating the finance issues of interest in this paper: only 11 firms in the panel indicated that finance is a major or very severe obstacle to operations. This may also refer to the issue of attrition in panels. In this case different contractors, Citizen Surveys in 2003 and $\varepsilon \varepsilon C$ Canada in 2007, conducted two crosssection surveys that also yielded panel data. In the 2007 survey $દ \varepsilon C$ Canada received a list of 716 firms from those surveyed in 2003. Of those 137 had to be excluded, which left a total potential of 579 panel establishments. In the end 231 firms were surveyed of which 40 appeared to have closed (World Bank, 2007). Unfortunately, the published data set does not include information on those firms and it is impossible to determine if it was those firms that were finance constrained in 2003 that had closed down in 2007.

\section{CONCLUSION}

This paper set out to examine access to finance and sources of finance as determinants of firm growth in South Africa. The literature indicated that small firms create employment and contribute to economic growth. There are many drivers of firm growth, but a key determinant is access to finance. The description of the data presented a clear profile of the firms in the 2007 World Bank Enterprise Survey and their access to finance. Firms that indicated that access to finance is a constraint to their operations were typically small and not as well established as those that do not experience finance as a constraint. They were not able to allow their clients to pay after delivery and they had to pay for their purchases before or on delivery. These firms also held less inventory and were less likely to own a generator or use their own transport to make shipments. Also, they were also less likely to pay for security or to provide formal training. They had lower capacity utilisation and were unlikely to be exporters or to introduce new products in response to competition. All this would indicate that firms that are finance constrained are more vulnerable to shocks and competition as well as weaker contributors to employment creation and growth. The results from the regression model confirmed that access to finance and different sources of finance are drivers of productivity at firm level.

The conclusion, for practitioners, is that finance seems to matter for a firm's efficiency. For firms that may experience finance constraints, the results show that getting their "financial house in order" is the key to improved efficiency. For example, firms need to build a sound credit history, appoint an external auditor and foster a healthy relationship with a bank.

For researchers, the question is whether financial markets are failing to allocate scarce savings among firms that need them for operation and investment. What causes firms to be finance constrained? Should government intervene to provide firms with access to finance? Answering such questions leads one back to Rogerson's (2008) view that one should consider both the demand and supply side of issues of access to finance, and this creates recommendations for further research. A supply-side view would involve a number of sub-themes, such as an assessment of government support aimed at enhancing access to finance, as well as an analysis of private sector programmes and the role of pro-poor microfinance services (Rogerson, 2008). 


\section{LIST OF REFERENCES}

Anon. (2010). Declaration by manufacturers and trade unions on industrial and economic policy interventions needed to create decent jobs. [On-line] Available: http://www.polity.org.ac.za. (Accessed 11 May 2010).

Becchetti, L. \& Trovato, G. (2002). The determinants of growth for small and medium sized firms. The role of the availability of external finance. Small Business Economics, 19(4), pp. 291-300.

Beck, T. \& Demurgüç-Kunt, A. (2006). Small and medium-size enterprises: Access to finance as a growth constraint. Journal of Banking and Finance, 30(11), pp. 2931-2943.

Beck, T., Demurgüç-Kunt, A., Laeven, L. \& Maksimovic, V. (2006). The determinants of financing obstacles. Journal of International Money and Finance, 25(6), pp. 932-952.

Berry, A., Von Blottnitz, M., Cassim, R., Kesper, A., Rajaratnam, B. \& Van Seventer, D. (2002). The economics of SMMEs in South Africa. Trade and Industrial Policy Strategies. [On-line] Available: http://www.edgegrowth.com/Portals/0/Documents/Seminal\%20Docs/THE\%20ECONOMICS\%200F\%20 SMMES\%20IN\%20SOUTH\%20AFRICA.pdf. (Accessed 20 January 2010)

Chandra, V., Moorty, L., Nganou, J., Rajartnam, B. \& Schaefer, K. (2001). Constraints to growth and employment in South Africa. Report No. 2: Evidence from the small, medium and micro enterprise firm survey. The World Bank Southern African Department Discussion Paper No. 15. [On-line] Available: http://www.essa.org.za/download/wb/Chandra_SMME_DP15.pdf. (Accessed 10 February 2010)

Claessens, S. \& Tzioumis, K. (2006). Measuring firms'access to finance. Paper prepared for the Conference: Access to Finance: Building Inclusive Financial Systems. [On-line] Available: http://info.worldbank.org/etools/docs/library/235462/ClaessensEtal_MeasuringFirmAccess.pdf. (Accessed February 2010)

Dobbs, M. \& Hamilton, R.T. (2007). Small business growth: Recent evidence and new directions. International Journal of Entrepreneurial Behaviour and Research, 13(5), pp. 296-322.

Du, J. \& Girma, S. (2009). Source of finance, growth and firm size - Evidence from China. UNU-WIDER, Helsinki, Finland. (Research Paper no. 2009/03).

Falkena, H., Abedian, I., Von Blotnitz, M., Coovadia, C., Davel, G. Madungandaba, J., Masilela, દ. \& Rees, S. (2001). SMEs access to finance in South Africa - a supply-side regulatory review by the Task Group of the Policy Board for Financial Services and Regulation. [On-line] Available: http://www.finforum.co.za. (Accessed 14 May 2010)

Fourie, FCvN. (2011). The South African unemployment debate: Three worlds, three discourses. SALDRU (Working Paper no. 63).

Magruder, J.R. (2009). High unemployment yet few small firms: The role of centralized bargaining in South Africa. [On-line] Available: http://ekon.sun.ac.za/seminars. (Accessed 20 January 2010)

Malhotra, M., Chen, Y., Crisciolo, A., Fan, Q., Ilieva Hamel, I \& Savchenko, Y. (2006). Expanding access to finance: Good practices and policies for micro, small and medium enterprises. World Bank: Washington. [On-line] Available:

http://info.worldbank.org/etools/docs/library/236032/SMEAccessToFinance_Final_083106.pdf. (Accessed 8 February 2010)

Naudé, W.A. (2008). Entrepreneurship in economic development. UNU-WIDER, Helsinki, Finland. (Research Paper no. 2008/20). 
Newberry, D. (2006). The role of small- and medium-sized enterprises in the futures of emerging economies. [0n-line] Available: http://earthtrends.wri.org/pdf_library/feature/eco_fea_sme.pdf. (Accessed 8 February 2010)

Nichter, S. \& Goldmark, L. (2009). Small firm growth in developing countries, World Development, 37(9), pp 1453-1464.

OECD. (2006). Financing SMEs and entrepreneurs. Policy Brief November. [On-line] Available: http://www.oecd.org/dataoecd/53/27/37704120.pdf. (Accessed 8 February 2010)

Rankin, N. (2001). The export behaviour of South African manufacturing firms. Paper presented at the TIPS Annual Forum, 10-12 September 2001, Johannesburg.

Rankin, N. (2006). The regulatory environment and SMMEs. Evidence from South African firm-level data. Development Policy Research Unit. (Working Paper No. 06/113).

Rogerson, C.M. (2004). The impact of the South African government government's SMME programmes: A ten-year review (1994-2003), Development Southern Africa, 21(5), pp. 765-784.

Rogerson, C.M. (2008). Tracking SMME development in South Africa: Issues of finance, training and the regulatory environment, Urban Forum, 19(1), pp. 61-81.

Skinner, C. (2005). Constraints to growth and employment in Durban: Evidence from the informal economy. School of Development Studies, University of KwaZulu-Natal, Durban. (Research Report No. 65).

StatsSA. See Statistics South Africa.

Statistics South Africa. (2010). Quarterly Labour Force Survey: Quarter 4. Statistics South Africa: Pretoria.

World Bank. (2007). Productivity and investment climate survey 2007. [0n-line] Available: http://www.enterprisesurveys.org. (Accessed 22 June 2009) 